\title{
UPAYA PENANGGULANGAN TINDAK PIDANA PERJUDIAN OLEH POLRESTA PADANG
}

\author{
Rike Amalia, Henni Muchtar, Muhammad Prima Ersya \\ Prodi Pendidikan Pancasila Dan Kewarganegaraan \\ Fakultas Ilmu Sosial Universitas Negeri Padang \\ email: rikeamalia@gmail.com
}

\section{Abstract}

Gambling is a form of social pathology. Gambling becomes a real threat or potensiil against social norms so that bias was threatening the social order. Thus gambling can be a barrier to national development that more material-spiritual. Therefore gambling should be dealt with by way of rational. One of these is a rational effort with enforcement of policy approaches as well as the process of penindakan against the perpetrators of the criminal law. The problems facing i.e. does criminal law policy in Indonesia that there is currently sufficient in order to handle the case of gambling and how the process of investigation of criminal law. As well as how the process of handling criminal law in the days to come to deal with criminal acts of gambling. The research method used is descriptive qualitative, i.e. by examining secondary data or analyzing a secondary legal materials with understanding the law as a regulatory device or positive norms within the system legislation governing human life. So this research is conceived as a research library (library research), namely research on secondary data.

Keywords: Tackling Crime, Gambling

\begin{abstract}
Abstrak
Perjudian adalah suatu bentuk patologi sosial. Perjudian menjadi ancaman yang nyata atau potensiil terhadap norma-norma sosial sehingga bias mengancam berlangsungnya ketertiban sosial. Perjudian dapat menjadi penghambat pembangunan nasional yang beraspek material-spiritual. Oleh karena itu perjudian harus ditangani dengan cara rasional. Salah satu usaha yang rasional tersebut adalah dengan pendekatan kebijakan penegakan serta proses penindakan terhadap pelaku hukum pidana. Permasalahan yang dihadapi yaitu apakah kebijakan hukum pidana di Indonesia yang ada saat ini telah memadai dalam rangka menangani kasus perjudian dan bagaimana proses penyidikan hukum pidana. Serta bagaimana proses penanganan hukum pidana di masa yang akan dating untuk menangani tindak pidana perjudian. Metode penelitian yang digunakan adalah deskriptif kualitatif, yaitu dengan mengkaji atau menganalisis data sekunder yang berupa bahan-bahan hukum sekunder dengan memahami hukum sebagai perangkat peraturan atau normanorma positif di dalam system perundang-undangan yang mengatur mengenai kehidupan manusia. Jadi penelitian ini dipahami sebagai penelitian kepustakaan (library research), yaitu penelitian terhadap data sekunder.

Kata kunci: Penanggulangan Tindak Pidana Perjudian, Perjudian
\end{abstract}




\section{PENDAHULUAN}

Perjudian adalah suatu bentuk penyakit masyarakat yang menjadi ancaman yang nyata atau berpotensial terhadap norma-norma sosial sehingga bisa mengancam berlangsungnya ketertiban umum. Dengan demikian perjudian dapat menjadi penghambat pembangunan nasional yang beraspek sumber daya manusia. Oleh karena itu perjudian harus ditangani dengan cara yang rasional. Salah satu usaha yang rasional tersebut adalah dengan pendekatan kebijakan hukum pidana. Hukum pidana digunakan untuk menyelesaikan masalah sosial khususnya dalam menangani kejahatan sebagai salah satu bentuk penyakit masyarakat dan satu bentuk patologi sosial seperti kasus perjudian. Penegak hukum pidana untuk menangani perjudian sebagai perilaku menyimpang yang harus terus dilakukan.

Moeljatno (2001:214) menjelaskan bahwa perkembangan kehidupan masyarakat yang begitu cepat sebagai hasil dan proses pelaksanaan pembangunan di segala bidang kehidupan sosial, politik, ekonomi, keamanan dan budaya selain membawa dampak positif, juga telah membawa dampak negatif salah satunya peningkatan kejahatan atau tindak pidana. Selanjutnya Moeljatno mengatakan istilah tindak pidana yakni sebuah perbuatan yang dilarang oleh suatu aturan hukum yang disertai dengan ancaman (sanksi) berupa pidana tertentu bagi siapa saja yang melanggar larangan tersebut salah satunya perbuatan tindak pidana perjudian.

Pengertian perjudian menurut Katini Kartono (2013:58) adalah pertaruhan dengan sengaja yaitu mempertaruhkan suatu nilai sesuatu yang dianggap bernilai dengan menyadari adanya resiko dan harapan-harapan tertentu pada peristiwa-peristiwa permainan, pertandingan, perlombaan dan kejadian-kejadian yang tidak/belum pasti hasilnya. Dalam Kitab Undangundang Hukum Pidana (KUHP) pasal 303 ayat 3 tentang pengertian judi disebutkan bahwa yang dimaksud denmgan permainan judi adalah tiap-tiap permainan, dimana pada umumnya kemungkinan mendapat uang bergantung pada peruntungan belaka, juga karena permainannya lebih terlatih atau lebih mahir. Disitu termasuk segala pertaruhan tentang keputusan perlombaan atau permainan lain-lain nya yang tidak diadakan antara mereka yang turut berlomba atau bermain, demikian juga segala pertaruhan lainnya.

Perjudian yang dikaitkan dengan alasan-alasan lain, antara lain perjudian yang dikaitkan dengan kebiasaan seperti adu ayam, Adu sapi, Adu kerbau, Karapan sapi, dan Adu domba/kambing. Pada mulanya permainan tersebut merupakan kesibukan pengisi waktu senggang guna menghibur yang bersifat rekreatif. Namun lambat laut ditambahkan unsur baru untuk merangsang gairah bermain dan menaikkan ketegangan serta pengharapan untuk menang, yaitu barang taruhan berupa uang atau benda yang bernilai. Praktik peruntungan nasib tersebut dari hari kehari justru semakin berkembang ke berbagai lapisan masyarakat di Indonesia termasuk Kota Padang. Perjudian juga tidak memandang usia, mulai dari anak-anak hingga lansia, bahkan kasus tindak pidana perjudian terhitung banyak yang telah diselesaikan oleh Polresta Padang. 
Judi bukan masalah baru di Indonesia. Sejak masa pemerintahan Orde Baru sampai saat ini maraknya. Untuk mengatasi masalah ini, lahirlah Undangundang Nomor 7 Tahun 1974 tentang Penertiban Perjudian. Undang-undang ini jelas menyatakan ancaman bahwa hukuman dalam Kitab Undang-undang Hukum Pidana (KUHP) untuk perjudian tidak sesuai lagi sehingga perlu diperberat. Bahkan Pasal pelanggaran judi dijadikan kejahatan dan hukumannya dinaikkan dai satu bulan menjadi empat tahun (Pasal 542 ayat 1), serta dari tiga bulan menjadi enam tahun (Pasal 542 ayat 2).

Karena hukum yang berlaku di Indonesia tidak mengizinkan adanya perjudian, maka kegiatan tersebut dilakukan secara sembunyi-sembunyi. Salah satunya tempat untuk dijadikan tempat berjudi adalah warung yang mana warung tersebut menjual makanan dan minuman. Salah satunya tempat perjudian di Kota Padang di samping stadion GOR Haji.Agus Salim turut memberikan kesempatan untuk pelaku judi melakukan kegiatannya dengan memfasilitasi beberapa jenis kartu seperti Remi, Domino, dan Koa. Praktik tersebut biasanya dilakukan pada sore dan malam hari.

Praktik judi online diselenggarakan melalui situs-situs internet antara lain www.5spoker.net dan www.dompet88.com, dapat diakses dengan mudah oleh para pelaku perjudian tersebut. Jika musim piala dunia sepak bola sedang berlangsung maka tidak ketinggalan bagi oknum yang menyediakan fasilitas tebak skor pertandingan. Salah satu judi bola online yang paling sering digunakan oleh para pelaku antara lain www.casino.sbobet.com, dan www.idola888.com. Adapun beberapa masalah yang timbul akibat perjudian ini adalah bahwa beberapa orang menjadi ketagihan baik bagi yang menang maupun yang kalah akan semakin penasaran dalam mencoba peruntungan dan akhirnya kehilangan banyak uang. Selain merugikan diri sendiri, kegiatan ini juga merugikan masyarakat karena selain meracuni jiwa seseorang, juga dapat meracuni perekonomian secara luas.

Pada hakikatnya perjudian adalah bertentangan dengan agama, kesusilaan dan moral Pancasila serta membahayakan masyarakat, bangsa dan negara dan ditinjau dari kepentingan nasional. Praktik perjudian tersebut perlu ditanggulangi karena didalam KUHP BAB XIV, Perjudian ditetapkan sebagai kejahatan terhadap kesusilaan sehingga dapat mengganggu ketertiban masyarakat. Semua aturan tersebut merupakan perangkat hukum yang jelas untuk melarang perjudian.

Penggunaan upaya hukum termasuk hukum pidana, merupakan salah satu upaya mengatasi masalah konflik sosial termasuk dalam bidang penegakan hukum. Disamping itu karena tujuannya adalah untuk mencapai kesejahteran masyarakat serta menjunjung tinggi hak azasi manusia, maka kebijakan hukum itupun termasuk dalam bidang kebijakan sosial, yaitu segala usaha yang rasional untuk mencapai kesejahteraan masyarakat. 
Berdasarkan latar belakang masalah di atas maka saya tertarik untuk melakukan penelitian dengan judul "Upaya Penanggulangan Tindak Pidana Perjudian oleh Polresta Padang".

\section{METODE PENELITIAN}

Jenis penelitian ini adalah penelitian lapangan berbentuk kualitatif. Pada penelitian ini berusaha menggambarkan suatu gejala, peristiwa dan kejadian, dengan kata lain penelitian deskriptif mengambil masalah atau memusatkan penelitian pada masalah aktual sebagaimana adanya pada saat penelitian dilakukan.

Lokasi penelitian ini dilaksanakan di Jl. Moh. Yamin, Kota Padang Sumatera Barat, tepatnya di Polisi Resort Kota Padang.

\section{HASIL DAN PEMBAHASAN}

Pembahasan ini didasarkan pada data hasil penelitian yang telah di uraikan di atas yang berhubungan dengan bentuk tindak pidana perjudian, wewenang dan tugas Polresta Padang dan kendala yang dihadapi Polresta Padang dalam menanggulangi tindak pidana perjudian di Kota Padang.

Dalam Pasal 2 Undang-undang No.2 tahun 2002 tentang Kepolisian Negara Republik Indonesia, fungsi kepolisian sebagai salah satu fungsi pemerintahan negara di bidang pemeliharaan keamanan dan ketertiban masyarakat, penengak hukum, pelindung, pengayom dan pelayanan kepada masyarakat. Sedangkan lembaga kepolisian adalah organ pemerintah yang ditetapkan sebagai suatu lembaga dan diberikan kewenangan menjalankan fungsinya berdasarkan peraturan perundang-undangan.

Selanjutnya Pasal 5 Undang-Undang No. 2 Tahun 2002 tentang Kepolisian Negara Republik Indonesia menyebutkan bahwa :

1. Kepolisian Negara Republik Indonesia merupakan alat negara yang berperan dalam memelihara keamanan dan ketertiban masyarakat, penegakkan hukum, serta memberikan perlindungan, pengayoman, dan pelayanan kepada masyarakat dalam rangka terpeliharanya keamanan dalam negeri.

2. Kepolisian Negara Republik Indonesia adalah Kepolisian Nasional yang merupakan satu kesatuan dalam melaksanakan peran sebagaimana dimaksud dalam ayat (1).

Dari beberapa pengertian di atas dapat dijelaskan bahwa polisi adalah alat negara yang menjalankan fungsi keamanan dan ketertiban masyarakat, perlindungan, pengayoman, dan pelayanan kepada masyarakat, dan dalam menjalankan fungsinya tersebut polisi harus memperhatikan penegakan HAM, hukum dan keadilan.

Upaya untuk mengatasi kejahatan (politik/kriminal) dengan menggunakan sarana penal yaitu melalui hukum pidana. Usaha-usaha non penal ini misalnya dalam melakukan penyantunan dan pendidikan sosial dalam rangka mengembangkan tanggung jawab sosial warga masyarakat, 
pelanggaran kesehatan jiwa masyarakat melalui pendidikan moral dan agama, peningkatan usaha-usaha kesejahteraan anak dan remaja, kegiatan patroli dan pengawasan lainnya setara berkelanjutan oleh polisi dan aparat keamanan lainnya.

Tujuan utama dari usaha-usaha non penal ini ialah memperbaiki kondisi-kondisi sosial tertentu. Secara tidak langsung usaha non penal mempunyai pengaruh preventif terhadap kejahatan. Dengan demikian dilihat dari sudut politik kriminal keseluruhan kegiatan preventif yang non penal itu sebenarnya mempunyai kedudukan yang sangat strategis, memegang posisi kunci yang harus diintensifkan dan efektifkan. Kegagalan dalam menggarap posisi strategis ini justru akan berakibat fatal bagi usaha penggulangan kejahatan. Kebijakan dengan hukum pidana menyangkut permasalahan perbuatan apa yang seharusnya dijadikan tindak pidana dan sanksi apa yang sebaiknya digunakan bagi si pelanggar. Hal tersebut berorientasi pada kebijakan (Muladi dan Barda Nawawi:1992).

Penanggulangan tindak pidana melalui upaya penal merupakan bagian dari penegakan hukum. Sebagai penegak hukum, upaya penal yang dilakukan oleh polisi yang bersifat represif dilakukan dengan menindak pelaku kejahatan yaitu dengan melakukan tindakan penyelidikan dan penyidikan. Sedangkan upaya non penal yang bersifat preventif dilakukan untuk mencegah terjadinya kejahan misalnya dengan melakukan penyuluhan-penyuluhan.

Adapun tindakan represif yang dilakukan kepolisian adalah :

1. Penyelidikan

Menurut Pasal 1 angka 5 KUHP, yang dimaksud dengan penyelidikan adalah penyelidikan serangkaian tindakan penyelidik untuk mencari dan menemukan suatu peristiwa yang diduga sebagai tindak pidana guna menentukan dapat atau tidaknya dilakukan penyidikan menurut cara yang diatur dalam undang-undang ini. Penyelidik adalah setiap Pejabat Polisi Negara Republik Indonesia (Pasal 4 Undang-Undang No.8 Tahun 1981 tentang Kitab Undang-Undang Hukum Acara Pidana). Selanjutnya penyelidik karena kewajibannya mempunyai wewenang sebagai berikut:

a. Menerima laporan atau pengaduan dari seseorang tentang adanya tindak pidana

b. Mencari keterangan dan alat bukti

c. Menyuruh berhenti seorang yang dicurigai dan menanyakan serta memeriksa tanda pengenal diri

Penyelidikan juga diatur dalam Pasal 102 Undang-Undang No.8 Tahun 1981 tentang Kitab Undang-Undang Hukum Acara Pidana, sebagai berikut :

a. Penyelidik yang mengetahui, menerima laporan atau pengaduan tentang terjadinya suatu peristiwa yang patut diduga merupakan tindak pidana wajib segera melakukan tindakan penyelidikan yang diperlukan. 
b. Dalam hal tertangkap tangan tanpa menunggu perintah penyidik, penyelidik wajib segera melakukan tindakan yang diperlukan dalam rangka penyelidikan sebagaimana tersebut pada pasal 5 ayat (1) huruf (b)

c. Terhadap tindakan yang dilakukan tersebut pada ayat (1) dan ayat (2) penyelidik wajib membuat berita acara dan melaporkan kepada penyidik sedaerah hukum.

2. Penyidikan

Penyidikan adalah serangkaian tindakan penyidik dalam hal dan menurut cara yang diatur dalam undang-undang ini untuk mencari serta megumpulkan bukti yang dengan bukti membuat terang tentang tindak pidana yang terjadi dan guna menemukan tersangkanya (Pasal 1 Angka 2 UndangUndang No.8 Tahun 1981 tentang Kitab Undang - Undang Hukum Acara Pindana). Selanjutnya penyidik yang mengetahui, menerima laporan atau pengaduan tentang terjadinya suatu peristiwa yang patut diduga merupakan tindak pidana wajib segera melakukan tindakan penyidikan yang diperlukan (Pasal 106 Undang-Undang No.8 Tahun 1981 tentang Kitab Undang-Undang Hukum Acara Pidana). Penyidikan merupakan upaya dalam menemukan dan mengumpulkan bukti - bukti untuk menjadikan kasus ini menjadi terang sehingga dapat menemukan tersangkanya. Adapun upaya pelaksanaan yang dilakukan oleh Polisi diantaranya penangkapan, penahanan, penggeledehan, penyitaan dan pemeriksaan surat

Berikutnya pengertian dari penangkapan, penahanan, penggeledehan, penyitaan dan pemeriksaan surat adalah :

a. Penangkapan adalah suatu tindakan penyidik berupa pengekangan sementara waktu kebebasan tersangka atau terdakwa apabila terdapat cukup bukti guna kepentingan penyidikan atau penuntutan dan atau peradilan dalam hal, serta menurut cara yang diatur dalam undang-undang ini. (Undang-Undang No.8 Tahun 1981 tentang Kitab Undang-undang Hukum Acara Pidana, Pasal 1 ayat (20). Dalam hal penangkapan biasa maka penyidik harus membawa surat perintah penangkapan yang meliputi identitas tersangka, alasan penangkapan, uraian singkat perkara kejahatan yang dipersangkakan, tempat ia diperiksa (UU No.8 Tahun 1981 tentang KUHP pasal 18 ayat (1).

b. Penahanan

Penahanan juga dilakukan dalam penuntutan oleh penuntut umum, hakim untuk kepentingan pemeriksaan sidang pengadilan. Pertimbangan adanya penahanan terhadap perkara antara lain :

1) Berdasarkan hasil pemeriksaan diduga keras telah melakukan tindak pidana berdasarkan bukti yang cukup.

2) Terhadap tersangka atau terdakwa yang melakukan tindak pidana atau melakukan percobaan maupun pemberian bantuan dalam tindak pidana tersebut dalam hal tindak pidana yang diancam dengan pidana 5 tahun atau lebih atau diduga melakukan tindak pidana lain sebagaimana dimaksud dalam Kitab Undang-Undang Hukum Acara Pidana pasal 21 ayat (4) huruf (b). 
3) Adanya keadaan yang menimbulkan kekhawatiran bahwa tersangka akan melarikan diri, merusak atau menghilangkan barang bukti dan akan mengulangi tindak pidana.

c. Penyitaan

Penyitaan adalah serangkaian tindakan penyidik untuk mengambil alih dan atau meyimpang di bawah penguasaannya benda bergerak atau tidak bergerak, berwujud atau tidak berwujud untuk kepentingan pembuktian dalam penyidikan, penuntutan dan peradilan. (Undang-Undang No. 8 Tahun 1981 tentang Kitab Undang-Undang Hukum Acara Pidana pasal 1 angka (16). Dalam melakukan penyitaan ini harus seizin ketua pengadilan negeri setempat.

Selanjutnya menurut Undang-Undang No. 8 Tahun 1981 tentang Kitab Undang-Undang Hukum Acara Pidana, penyidik memiliki wewenang sebagai berikut :

a. Menerima laporan atau pengaduan dari seorang tentang adanya tindak pidana.

b. Melakukan tindakan pertama pada saat di tempat kejadian.

c. Menyuruh berhenti seorang tersangka dan memeriksa tanda pengenal diri tersangka.

d. Melakukan penangkapan, penahanan, penggeledahan dan penyitaan.

e. Melakukan pemeriksaan dan penyitaan surat.

f. Mengambil sidik jari dan memotret seorang.

g. Memanggil orang untuk didengar dan diperiksa sebagai tersangka atau saksi.

h. Mendatangkan orang ahli yang diperlukan dalam hubungannya dengan pemeriksaan perkara.

i. Mengadakan penghentian penyidikan.

j. Mengadakan tindakan lain menurut hukum yang bertanggung jawab (Pasal 7 ayat (1) Undang-undang No. 8 Tahun 1981 tentang Kitab Undang-Undang Hukum Acara Pidana).

\section{a. Penanganan dan Penyidikan Tindak Pidana Perjudian}

Jika mendengar kata perjudian, seketika itu lansung terpikir pada uang dan alat dibuat judi. Di pikiran telah terntanam suatu pemikiran bahwa perjudian adalah tempat mencari uang tapi tidak semestinya. Selama ini aparat kepolisian tetap mengandalkan upayapencegahan sampai dengan cara penanganan yang bersifat lebih memasyarakat dalam artian pendekatanpendekatannya. Dengan melakukan bantuan kerjasama dari masyarakat. Karena hanya dengan beginilah yang diharapkan bagi seluruh masyarakat Indonesiamampu untuk jauh dari perjudian. Adapun upaya yang dilakukan aparat kepolisian dalam penanganan tindak pidana perjudian yaitu Refresif. Upaya ini dilakukan karena tindakan preventif sudah tidak diindahkan lagi. Maka dari itu aparat kepolisian melalui masyarakat dalam hal ini sebagai 
pengadu dalam setiap laporan yang masuk ke Satuan Reskrim dan ditindak lanjuti sesuai aturan yang berlaku.

Dalam Menangani Tindak Pidana Perjudian, Pada umumnya sama dengan menangani tindak pidana lainnya. Hanya saja ada yang membedakan tentang penanganan kasus-kasus tersebut. Perbedaannya hanya pada jenis kasus, penjeratan kasus sesuai dengan aturan yang berlaku. Tindak pidana perjudian terungkap kalua pelakunya tertangkap tangan. Dalam hal orangorang yang dianggap pelaku tertangkap tangan oleh polisi dan ditemukan barang bukti alat bukti judi, terhadap orang-orang tersebut akan diperiksa terlebih dahulu. Karena penangkapan dilakukan dengan penggrebekan, sehingga memang dimungkinkan ada orang-orang yang yang ikut ditangkap namun tidak ikut perjudian. Dalam hal orang-orang yang tidak ikut terlibat, itulah proses hokum pidana tidak akan dilanjutkan. Disisi lain, jika yang ditangkap tangan adalah orang yang terlibat atau sebagai pelaku judi. Tentu proses hokum akan berjalan sampai dengan persidangan.

Seseorang yang tertangkap tangan sedang melakukan tindak pidana harus melalui proses peradilan terlebih dahulu sebelum dapat dipidanakan. Itupun kalua memang terbukti bersalah. Selanjutnya, pelaku tindak pidana perjudian yakni seseorang yang dipidanakan berdasarkan keputusan pengadilan yang telah memperoleh kekuatan hukum tepat. Jadi pelaku tertangkap tangan tindak pidana perjudian tidak dapat langsung dijatuhkan sangsi pidana sebelum melalui proses peradilan. Dalam kasus tindak pidana perjudian yang pelakunya tertangkap tangan harus disertai alat bukti judi, maka dapat di uraikan sebagai berikut:

1) Perjudian diatur dalam Pasal 303 KUHP.

2) Dalam hal ini pelaku judi tertangkap tangan, pelaku ditangkap tanpa surat perintah, dengan ketentuan bahwa penangkap harus segera menyerahkan tertangkap beserta bukti yang ada pada penyidik atau penyidik pembantu yang terdekat (Pasal 18 ayat 22 KUHP).

"Tidak seorang pun dapat dijatuhi pidana, kecuali apabila pengadilan karena alat bukti yang sah menurut undang-undang, mendapat keyakinan bahwa seseorang yang dianggap dapat bertanggung jawab, telah bersalah atas perbuatan yang didakwakan atas dirinya"

b. Hambatan yang dihadapi oleh aparat kepolisian dalam menanggapi tindak pidana perjudian.

Adapun hambatan-hambatan yang ditemui dan dihadapi oleh aparat penegak hukum Polresta Padang dalam penanganannya:

1) Tempat perjudian berpindah-pindah karena bocornya informasi

2) Sulitnya mengungkap barang bukti Pembudayaan Judi di daerah tertentu

\section{c. Deskripsi Bentuk Tindak Pidana Perjudian yang Terjadi di Kota Padang}

Berdasarkan wawancara peneliti dengan bapak IPDA Denny Juniasyah, selaku Kepala Unit VI Satreskrim Polresta Padang di Kantor Polresta Padang pada hari Selasa tanggal 11 Desember 2018, mengatakan bahwa hampir 
seluruh bentuk perjudian ada di Kota Padang, mulai dari judi kartu remi, dadu, domino, koa, sabung ayam, tebak skor pertandingan olahraga, hingga judi yang dilakukan di pasar malam. Seluruh permainan tersebut tidak menjadi tindak pidana perjudian apabila orang yang bersangkutan didalam permainan tersebut tidak menaruh taruhan dengan uang atau barang yang bernilai dan bersifat unung-untungan. Taruhan yang paling sering terjadi yaitu dengan membayar makanan dan minuman bagi yang kalah dalam permainan kartu remi, domino maupun koa. Seluruh permainan yang memiliki unsur taruhan untug-untungan termasuk dalam tindak pidana perjudian.

Dari hasil penelitian yang dipaparkan di atas, bentu tindak pidana perjudian yang terjadi di Kota Padang merupakan seluruh permainan yang dijadikan sebagai sarana untuk bertaruh uang atau benda berharga. Permainan-permainan tersebut meliputi judi kartu remi, domino, koa, dadu, sabung ayam, tebak skor pertandingan olahraga, hingga judi yang dilakukan di pasar malam. Praktik tindak pidana perjudian tidak langsung dilakukan oleh pelakunya, melainkan bermula dari orang- orang yang bermain kartu tanpa adanya taruhan dengan tujuan sebagai sarana hiburan. Namun agar permainan menjadi menarik, para pelaku menjadikan permainan hiburan tersebut sebagai sarana mencari keuntungan dengan memasang taruhan menggunakan uang atau benda berharga.

Pada praktik tindakan pidana perjudian tebak skor pertandingan olahraga, awalnya hanya pertandingan olahraga biasa namun penonton pertandingan tersebut memberikan unsur teruhan degan harapan tim yang dijagokan menang dalam pertandingan olahraga tersebut.

Berbagai bentuk tindak pidana perjudian tersebut dapat dipidana berdasarkan Pasal 303 Sub 303 KUHP dengan hukuman penjara selamalamanya sepuluh tahun atau denda sebanyak-banyaknya dua puluh juta rupiah.

\section{d. Deskripsi Wewenang dan Tugas Polresta Padang dalam Menanggulangi Tindak Pidana Perjudian di Kota Padang}

Berdasarkan wawancara peneliti dengan bapak IPDA Denny Juniasyah, selaku Kepala Unit VI Satreskrim Polresta Padang di Kantor Polresta Padang pada hari selasa tanggal 11 Desember 2018, mengatakan bahwa wewenang dan tugas Polresta Padang sesuai dengan Undang-Undang No.2 tahun 2002 tentang kepolisian Negara Republik Indonesia. Polisi melakukan tindakan preventif berupa sosialisasi kepada masyarakat oleh satbinnmas (Satuan Bina Masyarakat) kemudian represif yaitu penyelidikan dan penyidikan.

Tindakan preventif berupa sosialisasi kepada masyarakat kota Padang melalui Satbinmas dilakukan dengan berkunjung ke setiap kelurahan. Sasaran penyuluhan yaitu pemuda yang sedang berkumpul maupun dengan sengaja mengumpulkan masyarakat di kelurahan untuk diberikan penyuluhan tentang kamtibmas termasuk larangan perjudian. Kami juga 
memasang baliho himbauan di beberaoa ruas jalan. Umumnya setiap anggota Polresta Padang yang berada di tengah-tengah masyarakat secara tidak langsung melakukan penyuluhan larangan perjudian.

Tindakan represif antara lain penyelidikan dan penyidikan. Polisi melakukan patrol yang telah terjadwal guna memantau keamanan masyaraat dan mencari suatu peristiwa yang diduga sebagai tindak pidana. Polisi berwenang menerima pengaduan dari masyarakat jika terdapat melakukan perjudian, maka polisi langsung melakukan penyelidikan di tempat perkara kejadian. Setelah diselidiki dan melihat barang bukti langsung dilakukan penyidikan antaralain penangkapan, penahanan, penggeledahan, dan penyitaan. Selanjutnya menyerahkan berkas perkara ke penuntut umum.

Dari pembahasan di atas dapat disimpulkan bahwa wewenang dan tugas yang dilakukan Polresta Padang telah dijalankan sesuai dengan Undang-Undang No.2 tahun 2002 tentang kepolisian Negara Republik Indonesia. Meskipun demikian mengalami beberapa kendala seperti kerjasama dengan masyarakat dan kurangnya presarana yang mendukung.

\section{PENUTUP}

\section{Kesimpulan}

a. Tindak pidana perjudian sebagai salah satu bentuk tindak pidana dibidang kesusilaan seharusnya tidak hanya diancam dengan pidana penjara dan pidana denda saja melainkan harus juga ditentukan pidana tambahan seperti pencabutan hak dalam menjalankan profesinya.

b. Setiap bentuk tindak pidana perjudian tidak hanya individu pribadi yang dimintai pertanggung jawabannya melainkan koorporasi atau pemerintahan setempat yang menjadi domisili pelaku yang juga bisa diminta pertanggung jawabannya.

c. Dalam hal penanganan dan penyidikan harus sangat mempertimbangkan keseimbangan antara kepentingan individu pelaku dan kepentingan masyarakat yang artinya harus disesuaikan dengan jenis perjudiannya.

d. Bentuk tindak pidana perjudian yang terjadi di Kota Padang merupakan seluruh permainan yang dijadikan sebagai sarana untuk bertaruh uang atau benda berharga. Permainan-permainan tersebut meliputi judi kartu remi, domino, koa, dadu jackpot, sabung ayam, tebak skor pertandingan olahraga, hingga judi yang dilakukan di pasar malam.

e. Wewenang dan tugas yang dilakukan Polresta Padang telah dilaksanakan sesuai dengan Undang-undang No.2 Tahun 2002 tentang Kepolisian Negara Republik yang terdiri dari upaya Prefentif yang bersifat mencegah dan Represif yang berisfat menindak.

f. Kendala yang didapat oleh Polresta Padang yaitu belum memiliki prasarana untuk mendeteksi perjudian yang dilakukan di sarana internet sehingga penertiban perjudian tidak berjalan dengan maksimal.

g. Hambatan yang dihadapi oleh aparat penegak hukum terkhusus penyidik kepolisian dalam menangani dan penyidikan kasus tindak 
pidana perjudian antara lain karena kurangnya kepedulian dan kesadaran masyarakat sehingga dalam oprasi pemberantasan dalam penanganan dan penyidikan tindak pidana perjudian seringkali mengalami kejanggalan. Disatu sisi lain perjudian yang telah dianggap sebagai adat atau budaya didaerah tertentu juga merupakan salah satu

\section{Saran} penghambatnya

a. Diharapkan kepada pihak-pihak yang ada di Polresta Padang untuk lebih sering melakukan sosialisasi keseluruhan masyarakat agar didalam masyarakat jika terdapat kegiatan perjudian Polresta Padang bisa langsung bertindak.

b. Diharapkan juga kepada pihak Polresta Padang untuk merealisasikan pengadaan prasarana khusus dalam menertibkan perjudian yang dilakukan di sarana internet.

c. Peneliti berharap ada peneliti lain yang mengadakan penelitian lanjutan untuk mengetahui sosialisasi dan pengadaan alat yang akan dilakukan oleh Polresta.

\section{Daftar Pustaka}

Haryanto. 2003. Indones, Negeri Jadi?. Jakarta : Yayasan Khasanah Insan Mandiri.

Kartini Kartono. 2013. Patologi Sosial-jilid I. Jakarta :Rajawali Pers.

Kepolisian Negara Republik Indonesia. Perpolisian Masyarakat, Buku Pedoman Pelatihan untuk Anggota Polri, Jakarta:Balai Pustaka,2006

Moeljatno. 1993. Asas-asas Hukum Pidana. Jakarta: Rineka Cipta.

Molcong, Lexy J. Metodologi Penelitian Kualitatif, Bandung : PT Remaja Rosda Karya, 2000.

Sugiono. 2012. Metode Penelitian Pendidikan. Bandung: Alfabeta. Sukardi. 2003. Metodologi Penelitian Pendidikan. Jakarta: Bumi Aksara

\section{Peraturan Undang-Undang}

Undang-Undang Republik Indonesia No. 2 Tahun 2002 tentang Negara Republik Indonesia.

Undang-Undang Republik Indonesia No. 7 Tahun 1974 tentang Perjudian. 